\title{
Trends, opportunities and scope of libraries during Covid-19 pandemic
}

\author{
Mohammad Asif $^{*}$, K. K. Singh ${ }^{2}$ \\ ${ }^{1}$ Sr. Library \& Information Assistant, ${ }^{2}$ Library \& Information Officer, Library and Information Centre, Indian Pharmacopoeia Commission, \\ Ministry of Health \& F.W., Govt. of India, Ghaziabad, Uttar Pradesh, India \\ *Corresponding Author: Mohammad Asif \\ Email: asif.atom@gmail.com
}

\begin{abstract}
The whole world is suffering with COVID-19 pandemic, every institution, industry and public domain has been affected with the Coronavirus. In this pandemic situation, libraries have been the gateways of relevant information and knowledge for conducting research and development on the related subject areas. The Library and Information services started to gain importance by providing researchers the opportunity to explore medical and scientific research, while prevention of the disease. This Article brought out recent technological advancements and preventive measures taken in order to enhance the knowledge of library professionals to promote library resources and services.
\end{abstract}

Keywords: Library resources, Information technology, COVID-19 Pandemic, Preventive measures, Library services.

\section{Introduction}

Libraries around the world have been facing lockdown challenges in providing access to its collections and services. All types of libraries have promoted their digital services during the corona virus pandemic situation. However, the physical resources are often put on demand by the users most preferably in the scientific organizations where research on drugs and pharmaceutical is being carried out for medical diagnosis and drug discovery. Libraries having significant number of e-resources may have enough opportunities to serve their users even in the lockdown period throughout the world. Several Libraries have brought out their digital services organizing virtual exhibitions, highlighting content on the websites and Lets Read Together online campaign. There have also been major efforts to boost access to the library resources online as well as offline, for example by increasing the number of e- Books/ e-Journals/CD-DVD, etc. in order to lower the risk of virus spread.

\section{Objectives of the Study}

There are following objective of the study:

1. To find out innovative ways to reach out library users

2. To explore opportunities to navigate through this challenge

3. To enhance learning and professional skills

4. To be prepared for New Normal Life

\section{Scope of the libraries}

The technological advancements and innovations have transformed the traditional libraries to the present smart Libraries. Today's Libraries offer wide range of innovative services to the users for their information need in the pandemic situation. There has been a paradigm shift of libraries in twenty first century. The major role of libraries in selective dissemination of Information and knowledge among its users predefine the scope of libraries. Libraries are the store houses of knowledge recorded in physical/digital medium. Libraries are growing organism and therefore continue to increase the library collection and services. Unlike the traditional libraries present trends of libraries includes digital/virtual mode of library collection and also offer remote access facility for their users. The application of Information and Communication Technologies (ICT), the Internet and particularly the World Wide Web have revolutionized library activities, hence there has been changes in the normal functioning of Libraries in the digital world. The present trend of library resources includes ebooks, e-resources, digital library, e- services etc. The future prospects of smart libraries would involve utilization of skill and knowledge whereas the information is also recorded, stored, retrieved and disseminated in the e-format at a large scale.

\section{Present trends of library services}

COVID-19 Pandemic does not seem to be eradicated completely. Librarians are looking forward, exciting to discover new services and opportunities to build a stronger library-user interface in the future. In order to achieve these goal libraries need to be equipped with latest infrastructure, information communication technologies and skilled manpower.

\section{Virtual library services}

1. Virtual Reference service like chat/e-mail

2. Self check-in and checkout of books

3. Scanning of chapters from books, journals articles for remote users

4. LibGuide- List of resources available in the library

5. Update library website dynamic content and useful tutorials

\section{About COVID-19 Virus and its spread \\ World Health Organization (WHO) has declared the COVID- 19 pandemic. COVID-19 or Coronavirus Disease is being caused by a newly discovered coronavirus. Old age people underlying medical problems like cardiovascular disease, diabetes, chronic respiratory disease, and cancer are}


more likely prone to serious illness. The Common symptoms of COVID-19 include high fever, tiredness and a dry cough. Other symptoms include shortness of breath, aches and pains, sore throat, and very few people will report diarrhoea, nausea or a runny nose. The Spread of Coronavirus people to people occurs through spread of droplets like respiratory droplets when infected person sneeze in the public domain.

In the case of Libraries where books come in contact of many persons at a time, therefore, the chances of virus transmission can occur by direct contact with infected user and indirect contact with surfaces in the library or with objects used by the infected user/staff. To understand and know more about the disease World Health Organization is releasing daily updates on the situation at the global level. To find out more about the virus, go through the WHO's research pages or the Massive Open Online Courses (MOOCs) on the virus prepared by the WHO.

\section{Handling of study materials in the libraries}

Although, there is a huge risk of infection through objects carrying coronavirus yet the use of library resources is equally important to carry out research on the on-going projects. Librarian now a day has to extend library services on a safer mode by following the standard operation procedure or the Government Guidelines. In the view of the above, some libraries have imposed a waiting period (quarantine) for Issue/ return of books. Different countries have set their own operating procedure to handle the Library resources, for example Australian Library and Information Association has suggested cleaning with alcohol wipes with plastic covers, such as DVDs, etc. The Italian Library Association, in addition to the above, has suggested that users could be asked to indicate if materials being returned have been in contact with someone with the virus.

\section{Preventive Measures and Guidelines / SOP for Libraries during COVID-19 Pandemic}

Libraries are facing challenges and restrictions in the lockdown. Governments regularly are taking different approaches, sometimes ordering the full closure of all institutions, in these situations library professionals may take following preventive measures to curb the spread of COVID19 through the libraries:

1. Stay at home if you feel sickness

2. Use appropriate sanitizer frequently

3. Roster of staff duty

4. Keep books at separate place at least for 48 hours when check in/check out

5. Maintain social distance

6. Follow good health and hygiene habits

7. Limiting concentration of users in reading room allowing just one table per user

8. Use mask and cover while sneezing or coughing

9. Avoid sneezing or coughing while handling books

10. Keeping surfaces clean, including toys and library computers surface like door knobs, switches and railing etc.

11. Use online platforms or social media to share Knowledge/Information.

12. Provide remote access of library resources to the users

13. Promote paperless work culture in the libraries

14. Frequently used items such as magazines and newspapers may only be accessible to people with gloves and masks, etc.

\section{Important/Useful links for Digital Library and E- Resources}

For all those library users who have developed or developing online reading habits, there are several digital libraries offering reading material free of cost, the links are given below:

Table 1:

\begin{tabular}{|c|l|l|l|}
\hline S. No. & Title / Name & \multicolumn{1}{|c|}{ Description } & Web Address / URL \\
\hline 1 & NDLI & $\begin{array}{l}\text { Educational materials available for all subject areas } \\
\text { like Technology, Social Science, Literature, Law, } \\
\text { Medical, etc. }\end{array}$ & $\underline{\text { https://ndl.iitkgp.ac.in/ }}$ \\
\hline 2 & $\begin{array}{l}\text { Internet } \\
\text { Archive }\end{array}$ & $\begin{array}{l}\text { Internet Archive: is a non-profit library of millions of } \\
\text { free books, movies, software, music, websites, and } \\
\text { more. }\end{array}$ & $\underline{\text { https://archive.org/ }}$ \\
\hline 3 & Hathi Trust & $\begin{array}{l}\text { HathiTrust is a partnership of academic and research } \\
\text { institutions, offering a collection of millions of titles } \\
\text { digitized from libraries around the world. }\end{array}$ & $\underline{\text { https://www.hathitrust.org/ }}$ \\
\hline 4 & $\begin{array}{l}\text { World Digital } \\
\text { Library }\end{array}$ & $\begin{array}{l}\text { The World Digital Library provides free access to } \\
\text { manuscripts, rare books, maps, photographs, and other } \\
\text { important cultural documents from all countries. }\end{array}$ & $\underline{\text { https://www.wdl.org/en/ }}$ \\
\hline 5 & Khan Academy & $\begin{array}{l}\text { Khan Academy non-profit educational organization. It } \\
\text { provides short lessons in the form of videos. }\end{array}$ & $\underline{\text { https://www.khanacademy.org/ }}$ \\
\hline 6 & Open Library & $\begin{array}{l}\text { Open Library is an open source towards a web page } \\
\text { for every book ever published. }\end{array}$ & $\underline{\text { https://openlibrary.org/ }}$ \\
\hline 7 & $\begin{array}{l}\text { Project } \\
\text { Gutenberg }\end{array}$ & $\begin{array}{l}\text { Project Gutenberg is a volunteer effort to digitize and } \\
\text { archive cultural works. }\end{array}$ & https://www.gutenberg.org/ \\
\hline
\end{tabular}




\section{Opportunities of Learning with the Virtual Platform/Webinar in the Libraries}

This is time for library professionals to avail opportunities and improve their skills/ability for outreach in virtual environment. They can organize virtual seminar or webinar, when a seminar is conducted online with the help of software it is called as the webinar. Now a day, there has been a trend of webinar and there are some specialized applications / software to conduct virtual meeting, webinar, video conferencing, live chat, etc. Web-based (virtual) seminar platform can be used to conduct online meetings, lectures and conferences. Webinar software provides online platform, where mutual interaction between the speakers and attendees takes place to carry out audio-visual communication. Webinar software provides real- time interactive features like multiple-hosts/clients, polls/voting, live chat, questions \& answers, screen sharing, etc. This technology is also useful in online teaching, lectures, training and learning purposes. Downloading/connecting Links are given hereunder for few applications/software, most of them offer free trial/module and require simple process to run as indicated in the connecting links. Libraries can use these facilities for knowledge sharing purpose among the staff/researchers/users. Following are widely used webinar hosting software worldwide:

Table 2:

\begin{tabular}{|c|c|c|c|}
\hline S. No. & Application/Software & Symbol & Downloading / Connecting Links \\
\hline 1 & Google Meet & Google Meet & https://meet.google.com/ \\
\hline 2 & GoToMeeting & & https://www.gotomeeting.com/en-in \\
\hline 3 & Business Hangouts & & https://business-hangouts.com/ \\
\hline 4 & Join Me & & https://www.join.me/ \\
\hline 5 & Microsoft team & & $\begin{array}{l}\text { https://www.microsoft.com/en- } \\
\text { in/microsoft-365/microsoft-teams/group- } \\
\text { chat-software }\end{array}$ \\
\hline 6 & My Own Conference & & https://myownconference.com/ \\
\hline 7 & Skype for Business & & https://www.skype.com/en/get-skype/ \\
\hline 8 & CISCO Webex & & $\begin{array}{l}\text { https://www.webex.com/content/webex/c/e } \\
\text { \%20n_US/index/downloads.html/ }\end{array}$ \\
\hline 9 & Zoho Meeting & & https://www.zoho.com/meeting/ \\
\hline 10 & Zoom & & https://zoom.us/signin \\
\hline
\end{tabular}




\section{Conclusion}

Technological advancements have revolutionized the library services in digital era. Libraries on the web have become more competent and confident in terms of resource management and digitalization. Information societies are seeking information in digital format, therefore, library services depends upon skilled professionals. Library plays vital role in data acquisition, storage, analysis, interpretation and dissemination of information among the library users. This Article has brought out opportunity to learn recent technological advancements in order to maximize the usage of library resources and services in worldwide lockdown and pandemic situations prevailing in the country. This article will provide an overview on preventive measures and current trends in libraries to play proactive role in the present and post pandemic situation.

\section{Source of Funding}

None.

\section{Conflict of Interest}

None.

\section{References}

1. COVID-19 and the Global Library Field accessed on 02/06/2020 from https://www.ifla.org/covid-19-and-libraries

2. Modes of transmission of virus causing COVID-19: implications for IPC precaution recommendations accessed on 02/06/2020 from https://www.who.int/newsroom/commentaries/detail/modes-of-transmission-of-viruscausing-covid-19-implications-for-ipc-precautionrecommendations

3. Top $10+$ Webinar Software in 2020 accessed on $08 / 06 / 2020$ from https://www.softwareworld.co/webinar-software/

4. Paramanik, Amiya (2015) The Prospects of Library and Information Science Professionals in Post-Industrial Era, Int $J$ Interdiscip Multidiscip Stud 2015;2(9):48-52.

5. Singh KK, Asif M, Emerging trends and technologies for digital transformation of libraries. IP Indian J Libr Sci Inf Technol 2019;4(2):41-3.

How to cite: Asif M, Singh KK, Trends, opportunities and scope of libraries during Covid-19 pandemic. IP Indian J Libr Sci Inf Techno 2020;5(1):24-7. 